\title{
Effects of subcutaneous calcium administration at calving on mineral status, health, and production of Holstein cows
}

\author{
H. Amanlou, ${ }^{*}$ A. P. Akbari, ${ }^{*}$ N. E. Farsuni, ${ }^{*}$ and N. Silva-del-Ríot ${ }^{1}$ \\ *Department of Animal Science, University of Zanjan, Zanjan, Iran \\ †Veterinary Medicine Teaching and Research Center, University of California-Davis, 18830 Road 112, Tulare 93274
}

\begin{abstract}
The objective of this study was to determine effects of subcutaneous (s.c.) infusions of Ca at calving day on serum concentrations of $\mathrm{Ca}, \mathrm{P}, \mathrm{Mg}, \beta$-hydroxybutyrate (BHB), glucose, body condition score (BCS), milk yield, and health in fresh cows receiving a dietary cation-anion difference diet during the dry period. Three hundred seventy-five fresh Holstein cows were blocked based on parity (143 cows in first parity, 108 cows in second parity, and 124 cows in third or greater parity) and randomly assigned to 1 of 4 experimental treatments immediately after calving. Treatments were control group without infusion (control; $\mathrm{n}=190$ ); 1 s.c. infusion of $250 \mathrm{~mL}$ of $40 \%$ Ca borogluconate $\left(1 \mathrm{SC}_{250} ; \mathrm{n}\right.$ $=72$ ) at calving; 1 s.c. infusion of $500 \mathrm{~mL}$ of $40 \% \mathrm{Ca}$ borogluconate $\left(\mathrm{SC}_{500 ;} \mathrm{n}=63\right)$ at calving; 2 s.c. infusions of $250 \mathrm{~mL}$ of $40 \%$ Ca borogluconate, one immediately after calving and the second 12 to $18 \mathrm{~h}$ after first infusion $\left(2 \mathrm{SC}_{250 ;} \mathrm{n}=50\right)$. Blood samples were collected immediately after parturition and at 1, 2, 4, and $7 \mathrm{~d}$ in milk (DIM) for $\mathrm{Ca}, \mathrm{P}$, and $\mathrm{Mg}$ determination. Milk production, milk composition, and somatic cell count were recorded monthly up to 90 DIM. The evaluation of BCS was performed at calving and at 38 DIM. A subset of 9 cows per treatment group was randomly chosen to measure serum concentration of glucose and $\mathrm{BHB}$ at 2, 4, and 7 DIM. Total serum Ca in $1_{S^{250}}(8.95 \mathrm{mg} /$ $\mathrm{dL}),{ }^{\mathrm{SCC}} \mathrm{C}_{500}(9.27 \mathrm{mg} / \mathrm{dL})$, and $2 \mathrm{SC}_{250}(9.07 \mathrm{mg} / \mathrm{dL})$ was greater during the first week postpartum compared with control $(8.45 \mathrm{mg} / \mathrm{dL})$. Serum concentrations of $\mathrm{P}$, $\mathrm{Mg}$, BHB, glucose, and milk yield were not affected by treatments. The dry matter intake during the first 24 $\mathrm{h}$ after calving was higher for treatments $1 \mathrm{SC}_{250}(13.5$ $\mathrm{kg}), 1 \mathrm{SC}_{500}(15.0 \mathrm{~kg})$, and $2 \mathrm{SC}_{250}(15.6 \mathrm{~kg})$ relative to control $(12.5 \mathrm{~kg})$. Milk somatic cell counts were lower for $1 \mathrm{SC}_{500}(90.5$ cells $/ \mathrm{mL})$ and $2 \mathrm{SC}_{250}(82.2$ cells $/ \mathrm{mL})$ than control $(132.8$ cells $/ \mathrm{mL})$. Risk ratio was $>1$ for development of metritis, and clinical and subclinical
\end{abstract}

Received December 31, 2015

Accepted July 12, 2016.

${ }^{1}$ Corresponding author: nsilvadelrio@ucdavis.edu endometritis in control cows relative to $2 \mathrm{SC}_{250}$ cows, which indicates a higher risk of developing disease for control cows (2.03, 1.7, and 1.8 times, respectively). These results suggest that prophylactic s.c. infusions of $\mathrm{Ca}$ at calving can improve postpartum Ca status in Holstein cows and intake at 1 DIM. Given the reduction of metritis, clinical and subclinical endometritis, and subclinical hypocalcemia with treatment, the effect of s.c. Ca supplementation on immune status warrants further investigation.

Key words: calcium status, subcutaneous infusion, uterine disease, fresh cow

\section{INTRODUCTION}

Hypocalcemia is a peripartum metabolic disorder observed when cows are unable to maintain normal blood $\mathrm{Ca}$ concentrations at the time of calving (Goff and Horst, 1997). The prevalence of clinical hypocalcemia has been reported to be 5\% (McLaren et al., 2006), whereas in multiparous cows subclinical hypocalcemia (SCH) can be as high as 54\% (Reinhardt et al., 2011). Calcium not only plays an essential role on skeletal and smooth muscle contractions but also in immune function of dairy cows (Kimura et al., 2006). Several studies found clinical hypocalcemia associated with multiple postpartum disorders such as dystocia, uterine prolapse, retained fetal membranes (RFM), endometritis, poor fertility, mastitis, and reduced rumen and abomasum motility (Curtis et al., 1983; Borsberry and Dobson, 1989; Goff, 2004). Although clinical hypocalcemia is clearly a critical disorder for fresh cows, $\mathrm{SCH}$ has been shown to have an important detrimental effect on postpartum health. Cows with $\mathrm{SCH}$ are at greater risk for metritis and displaced abomasum culling and show an impaired hepatic lipid metabolism (Chapinal et al., 2011; Martínez et al., 2012; Roberts et al., 2012; Chamberlin et al., 2013).

Unfortunately no cow-side tests are available for immediate diagnosis of hypocalcemia on farm. Thus, to prevent $\mathrm{SCH}$ some herds could benefit from implementing prophylactic strategies such as anionic salt programs. Although this strategy has decreased the 
incidence of SCH in some studies (Oetzel et al., 1988; Moore et al., 2000), it was unsuccessful in Ramos-Nieves et al. (2009). Alternative prophylactic approaches are Ca supplementation following calving by the oral, intravenous (i.v.), or subcutaneous (s.c.) route (Melendez et al., 2002; Sampson et al., 2009; Oetzel and Miller, 2012; Mohebbi-Fani and Azadnia, 2012; Blanc et al., 2014). When cows on an anionic program were supplemented with oral or i.v. Ca, no effects were found with regard to plasma concentration of macrominerals $(\mathrm{Ca}$, $\mathrm{P}, \mathrm{Mg}$ ) or metabolites (NEFA, BHB, and glucose) at 2, 3, 6, 9, and 12 DIM (Melendez et al., 2002). However, Oetzel and Miller (2012) reported that lame cows and high-producing multiparous cows responded positively to oral Ca supplementation. Based on a recent kinetic study (Blanc et al., 2014), the prophylactic treatment of hypocalcemia with i.v. Ca resulted in an initial hypercalcemia, peaking $1 \mathrm{~h}$ after treatment initiation, followed by hypocalcemic levels that reached nadir 24 $\mathrm{h}$ after treatment (Blanc et al., 2014). Thus, i.v. Ca administration may not be the best route for administration.

In cases of clinical hypocalcemia, s.c. Ca is being used after i.v. Ca treatment to prolong Ca absorption (Oetzel, 1988; Goff, 1999; Brozos et al., 2011), but its application as a prophylactic strategy has received minimal attention. Literature on s.c. Ca infusion for cows as a prophylactic strategy to prevent $\mathrm{SCH}$ is scarce (Mohebbi-Fani and Azadnia, 2012; Miltenburg et al., 2016). We hypothesize that s.c. Ca could be used as a prophylactic strategy to reduce hypocalcemia on dairies. Our objective was to study various s.c. Ca supplementation regimens at calving to evaluate implications on macromineral status and blood metabolites, as well as production and animal health of Holstein cows receiving a DCAD dietary cation-anion difference diet during the dry period.

\section{MATERIALS AND METHODS}

\section{Cow and Herd Management}

The study was conducted on an Iranian commercial dairy farm housing 3,000 Holstein dairy cows, with an average daily milk production of $34 \mathrm{~kg} / \mathrm{d}$. A total of 375 Holstein cows in their first $(\mathrm{n}=143)$, second $(\mathrm{n}=108)$, and third or greater $(\mathrm{n}=124)$ lactation were enrolled in the study. The experiment was conducted from April 2013 to August 2013. During the close-up period, $18 \pm$ $3 \mathrm{~d}$ before expected calving date, cows were housed in a dry-lot facility and fed once a day a prepartum diet formulated to have a negative calculated DCAD $(-130$ $\mathrm{mEq} / \mathrm{kg}$; Table 1) through limiting the supply of $\mathrm{Na}$ and $\mathrm{K}$ and increasing the amount of supplemental $\mathrm{Cl}$.
After showing primary signs of calving, farm personnel moved cows to individual calving pens where they stayed up to $24 \mathrm{~h}$ after calving for DMI measurements. Farm personnel were present at the maternity pen 24 $\mathrm{h} / \mathrm{d}$ in $8 \mathrm{~h}$ shifts. Once cows calved, they were offered $31 \mathrm{~kg}$ of feed on as-fed basis. Feed was pushed every 8 $\mathrm{h}$ at the beginning of each maternity personnel shift. Refusals were weighed back $24 \mathrm{~h}$ after feeding. Twentyfour hours after calving, cows were moved to a freestall barn and fed a TMR diet ad libitum 3 times a

Table 1. Ingredient and nutrient profile of close-up and fresh cow diets (DM basis)

\begin{tabular}{|c|c|c|}
\hline \multirow[b]{2}{*}{ Item } & \multicolumn{2}{|c|}{ Diet } \\
\hline & Close-up & Fresh \\
\hline \multicolumn{3}{|l|}{ Ingredient ( $\%$ of DMI) } \\
\hline Legume hay, mature & 16.96 & 24.13 \\
\hline Corn silage, normal & 36.93 & 18.41 \\
\hline Wheat straw & - & 1.54 \\
\hline Barley grain, ground, dry & 18.44 & 4.89 \\
\hline Corn grain, ground, dry & 8.48 & 18.92 \\
\hline Cottonseed, whole seed with lint & 4.11 & 7.47 \\
\hline Canola meal & 2.74 & 2.45 \\
\hline Soybean meal, solvent, $44 \% \mathrm{CP}$ & 4.07 & 10.51 \\
\hline Meat meal & - & 2.03 \\
\hline Soybean seeds, whole heated & 0.90 & 4.83 \\
\hline Calcium soap of fatty acids & 0.48 & 0.90 \\
\hline Wheat, bran & 1.62 & - \\
\hline Salt & - & 0.17 \\
\hline Sodium bicarbonate & - & 0.89 \\
\hline Mg oxide & - & 0.22 \\
\hline Calcium carbonate & 1.53 & 0.72 \\
\hline Calcium phosphate (Di-) & - & 0.17 \\
\hline Vitamin premix & $2.03^{1}$ & $1.0^{2}$ \\
\hline Bentonite & - & 0.10 \\
\hline Toxin binder & - & 0.10 \\
\hline Ammonium chloride & 0.85 & - \\
\hline $\mathrm{Mg}$ sulfate & 0.85 & - \\
\hline \multicolumn{3}{|l|}{ Chemical composition } \\
\hline $\mathrm{NE}_{\mathrm{L}}^{3}(\mathrm{Mcal} / \mathrm{kg})$ & 1.6 & 1.72 \\
\hline $\mathrm{CP}(\%)$ & 13.3 & 18.7 \\
\hline $\operatorname{RDP}(\%)$ & 10.0 & 13.1 \\
\hline RUP (\%) & 3.30 & 5.6 \\
\hline NDF (\%) & 34.2 & 31.7 \\
\hline Forage NDF (\%) & 25.3 & 21.1 \\
\hline $\operatorname{ADF}(\%)$ & 21.7 & 21.8 \\
\hline NFC $(\%)$ & 42.2 & 38.7 \\
\hline Ether extract (\%) & 3.9 & 5.7 \\
\hline $\mathrm{Ca}(\%)$ & 1.27 & 1.10 \\
\hline $\mathrm{P}(\%)$ & 0.35 & 0.50 \\
\hline $\mathrm{Mg}(\%)$ & 0.20 & 0.35 \\
\hline $\mathrm{Na}(\%)$ & 0.02 & 0.34 \\
\hline $\mathrm{K}(\%)$ & 1.20 & 1.40 \\
\hline $\mathrm{Cl}(\%)$ & 0.81 & 0.33 \\
\hline $\mathrm{S}(\%)$ & 0.35 & 0.22 \\
\hline $\mathrm{DCAD}^{4}(\mathrm{mEq} / \mathrm{kg})$ & -130 & 276 \\
\hline
\end{tabular}

${ }^{1} 8,000 \mathrm{IU}$ of vitamin $\mathrm{A} / \mathrm{kg}, 2,500 \mathrm{IU}$ of vitamin $\mathrm{D}_{3} / \mathrm{kg}$, and $100 \mathrm{IU}$ of vitamin $\mathrm{E}$.

${ }^{2} 1,800,000 \mathrm{IU}$ of vitamin $\mathrm{A} / \mathrm{kg}, 400,000 \mathrm{IU}$ of vitamin $\mathrm{D}_{3} / \mathrm{kg}, 8,000 \mathrm{IU}$ of vitamin E, and 3,000 $\mathrm{mg}$ of antioxidant.

${ }^{3}$ Estimated from NRC (2001).

${ }^{4} \mathrm{DCAD}$ calculations were performed according to the following equation $(\mathrm{NRC}, 2001)$ : DCAD $(\mathrm{mEq} / \mathrm{kg})=(\mathrm{Na}+\mathrm{K})-(\mathrm{Cl}+\mathrm{S})$. 
day at 0800,1600 , and $2200 \mathrm{~h}$. All cows were milked 3 times a day at 0600,1400 , and $2000 \mathrm{~h}$. The ingredient and nutrient composition of the diets fed to close-up and fresh cows are represented in Table 1. National Research Council (NRC, 2001) requirements were used for diet formulation.

Immediately after calving, cows were blocked based on parity $(1,2$, or $\geq 3)$ and randomly assigned to 1 of 4 experimental treatments using a random number generator (rand function, Microsoft Excel, 2010, Microsoft Corp., Redmond, WA). Afterward, cows were allocated to treatment consecutively. Treatment groups were (1) no s.c. infusion of $\mathrm{Ca}$ (control; $\mathrm{n}=190$ ), (2) 1 s.c. infusion of $250 \mathrm{~mL}$ of $40 \%$ Ca borogluconate $\left(\mathbf{1 S C}_{250}\right.$; $\mathrm{n}=72 ; 7.6 \mathrm{~g}$ of Ca), (3) 1 s.c. infusion of $500 \mathrm{~mL}$ of $40 \%$ Ca borogluconate $\left(\mathbf{1 S C}_{500} ; \mathrm{n}=63 ; 15.2 \mathrm{~g}\right.$ of $\left.\mathrm{Ca}\right)$, and (4) 2 s.c. infusion of $250 \mathrm{~mL}$ of $40 \%$ Ca borogluconate, one immediately after calving and the second 12 to $18 \mathrm{~h}$ after first administration $\left(\mathbf{2 S C}_{250} ; \mathrm{n}=50\right.$; $15.2 \mathrm{~g}$ of Ca). Cows calving from 0600 to $1800 \mathrm{~h}$ were randomly assigned to 1 of the 4 treatments, although cows calving from 1800 to $0600 \mathrm{~h}$ were only assigned to the control because researchers were not present at the farm to administer treatments. Similar management was administered during the day and night shift by maternity employees.

Animals showing signs of milk fever, mastitis, pneumonia, laminitis, dystocia, and rectal temperature $\left(\geq 39.4^{\circ} \mathrm{C}\right)$ before treatment application were not included in the study. Prior to infusion, the Ca solution was warmed to body temperature. Only $50 \mathrm{~mL}(1.5$ $\mathrm{g}$ of $\mathrm{Ca}$ ) was given per injection site located behind the shoulder. After each injection, the site was gently massaged. Cows showed no signs of irritation after treatment.

\section{Blood Sample Collection and Laboratory Analysis}

Blood samples $(10 \mathrm{~mL})$ were taken from the coccygeal vein, using an evacuated tube without anticoagulant (Vacumed, no additive, FL Medical, Torreglia, Italy) and allowed to clot for $20 \mathrm{~min}$. A total of 5 samples were collected from all cows: immediately after calving (before treatment), and at 1, 2, 4, and 7 DIM, 3 to $4 \mathrm{~h}$ after feeding (between 1000 to $1100 \mathrm{~h}$ ). Clotted samples were centrifuged (Hettich; D-78532T Tuttlingen, Germany) at $2,000 \times g$ for $10 \mathrm{~min}$ at $20^{\circ} \mathrm{C}$ to obtain serum. Serum was stored at $-20^{\circ} \mathrm{C}$ until analysis. Serum samples were analyzed for total Ca with OCresolphthalein-complexone method (Baginski et al., 1973), Mg with the Xylidyl blue method (Endres and Rude, 1999), and P using the UV method (Endres and Rude, 1999) by Pars Azmun kits (Pars Azmun Laboratory, Tehran, Iran). Absorbance was measured using a spectrophotometer (Perkin-Elmer, Coleman Instruments Division, Oak Brook, IL). The first 9 cows randomized to each treatment group were also sampled at 2, 4, and 7 DIM. In these cows, glucose by Glucometer (Glucometer; Glucotrend, Roche, UK) and BHB with enzymatic method based on 3-hydroxybutyrate dehydrogenase by Randox Kits (Cat. No. RB 1007, Randox Laboratories Ltd., Crumlin, County Antrim, UK) using a spectrophotometer (UNICCO, 2100, Zistchemi Co., Tehran, Iran) were measured.

\section{Milk Yield, Milk Composition, SCC, and BCS}

Milk composition (fat, protein, and lactose) and SCC were determined using a MilkoScan Minor (CombiFoss 78110; Foss Analytical A/S, Hillerød, Denmark). Cows were scored for body condition at calving and at 38 DIM by 1 trained evaluator with 12 yr of experience using a 5-point scale with 0.25 increments (Wildman et al., 1982).

\section{DMI}

Individual DMI was evaluated for the 24-h period after calving as cows were kept in individual calving pens. The feed offered at calving and refused at $24 \mathrm{~h}$ after calving was measured. The DM of the feed offered and of the refusal were determined in a drying oven at $100^{\circ} \mathrm{C}$ for $48 \mathrm{~h}$ (AOAC, 1990; method 930.15).

\section{Binary Variables and Case Definition}

The incidence of postpartum disorders, including milk fever, SCH, RFM, metritis, subclinical and clinical endometritis, and culling, were recorded up to 21 DIM. Subclinical hypocalcemia was diagnosed as serum Ca concentration $\leq 8.5 \mathrm{mg} / \mathrm{dL}$ at 1 or 2 DIM (Oetzel and Eastridge, 2013). Retained fetal membranes were defined as failure to expel fetal membranes within $24 \mathrm{~h}$ of parturition (Kelton et al., 1998). Puerperal metritis was defined as a discolored, foul-smelling uterine discharge with fever (rectal temperature $>39.4^{\circ} \mathrm{C}$; Sheldon et al., 2006). During fresh cow evaluations, one of the researchers (A.P.A), a veterinarian with 16 yr of clinical experience, evaluated postpartum cows daily from calving to 14 DIM to look for signs of disease with special focus on metritis. Rectal exams were performed at 7 DIM. If abnormal vaginal discharge was observed rectal temperature was evaluated with a digital thermometer (TM 22, Healer-co, Giessen, Germany). Clinical endometritis was defined as mucopurulent or purulent ( $>50 \%$ pus) uterine discharge detectable in the vagina after 21 DIM (Sheldon et al., 2006). Subclinical endometritis was diagnosed at $38 \pm 3$ DIM using a 
uterine saline solution flush $(0.9 \% \mathrm{NaCl})$. Subclinical endometritis was defined as a smear with $5 \%$ or more of polymorphonuclear cells (Gilbert et al., 2005).

\section{Statistical Analysis}

All statistical analysis were conducted in SAS (version 9.1; SAS Institute Inc., Cary, NC). Prior to treatment administration, dry period length was evaluated across all treatment groups using the general linear models procedure of SAS (PROC GLM). Logistic regression (PROC GENMOD) was used to study the proportion of cows in each treatments group before treatment administration for parity $(1,2$, or $\geq 3)$, BCS $(\leq 3,3.25,3.5$, and $\geq 3.75)$, and Ca status $(8.5 \geq$ serum $\mathrm{Ca}>8.5 \mathrm{mg} / \mathrm{dL})$. The aforementioned variables were also assessed for control cows calving from 0600 to 1800 $\mathrm{h}$ relative to control cows calving from 1800 to $0600 \mathrm{~h}$.

Serum concentrations of glucose, $\mathrm{BHB}, \mathrm{Ca}, \mathrm{Mg}$, and $\mathrm{P}$ as well as milk yield, milk composition (fat, protein, and lactose), and milk SCC were analyzed as repeated measures by using a mixed model procedure (PROC MIXED). All SCC data were log-transformed to correct for heterogeneity of variance. Serum levels of Ca, $\mathrm{Mg}$, and $\mathrm{P}$ obtained before treatment administration were used to covariately adjust the data. Cow nested within treatments was included in the model as a random effect. Time (DIM and months) was included in the model as a repeated variable. Covariance structures were tested, and the most appropriate structure based on the lowest Akaike information criterion, corrected Akaike information criterion, and Bayesian information criterion values was used for each analysis (Littell et al., 1998). The following model was used:

$$
\begin{aligned}
\mathrm{Y}_{\mathrm{ijk}}= & \mu+\mathrm{T}_{\mathrm{i}}+\operatorname{Cow}\left(\mathrm{T}_{\mathrm{i}}\right)+\text { time }_{\mathrm{k}}+\mathrm{P}_{\mathrm{j}}+(\mathrm{P} \times \mathrm{T})_{\mathrm{ij}} \\
& +(\text { time } \times \mathrm{T})_{\mathrm{ik}}+\left(\mathrm{P} \times \text { time }_{\mathrm{jk}}+\mathrm{e}_{\mathrm{ijk}},\right.
\end{aligned}
$$

where $Y_{i j k}=$ dependent variables, $T_{i}=$ fixed effect of treatment, $\operatorname{Cow}\left(\mathrm{T}_{\mathrm{i}}\right)=$ random effect of cow nested in treatment, time $_{\mathrm{k}}=$ fixed effect of time, $\mathrm{P}_{\mathrm{j}}=$ fixed effect of parity $(1,2$, and $\geq 3),(\mathrm{P} \times \mathrm{T})_{\mathrm{ij}}=$ fixed effect of parity by treatment interaction, $(\text { time } \times \mathrm{T})_{\mathrm{ik}}=$ fixed effect of time by treatment interaction, $(\mathrm{P} \times \text { time })_{\mathrm{jk}}$ $=$ fixed effect of time by parity interaction, and $\mathrm{e}_{\mathrm{ijk}}=$ random error term. Data were reported as least squares means and were considered significant if $P<0.05$ and a tendency if $P<0.1$. If a significant interaction of treatment by time was present, differences between treatments at every time point were determined using the SLICE option of the LSMEANS statement from the MIXED procedure of SAS.
Dry matter intake in the first $24 \mathrm{~h}$ postcalving and BCS changes were analyzed by ANOVA using the GLM procedure (PROC GLM). Models included treatment, parity, and their interaction. Data from diseases (RFM, metritis, and subclinical and clinical endometritis) and early herd removal were analyzed with PROC GENMOD with binomial distributions and log link functions. For each binary variable, calcemic status at calving (normocalcemia vs. hypocalcemia) was offered as a covariate. Logistic regression model for $\mathrm{SCH}$ was calculated using the GENMOD procedure with generalized estimating equations (Liang and Zeger, 1986) with compound of symmetry covariance structure (Dohoo et al., 2003) using binomial distribution and log link functions and with the REPEATED statement (subject $=$ cow). The logistic regression model included the fixed effects of treatment, parity ( 2 vs. 1 and $\geq 3$ vs. 1) and their second-order interaction. Binary variables were covariately adjusted by calcemic status at calving (normocalcemia vs. hypocalcemia) except for $\mathrm{SCH}$. Independent variable interaction terms were considered statistically significant if $P \leq 0.05$. Fixed effect second order interactions and covariate (Ca status) were removed by manual backward stepwise elimination if they were not significant at $P>0.10$.

\section{RESULTS AND DISCUSSION}

Prior to s.c. Ca infusion, no differences were found in the proportions of cows with parity 1,2 , or $\geq 3$ ( $P$ $=0.75)$, BCS $\leq 3,3.25,3$. 5 , or $\geq 3.75(P=0.88)$, Ca status at calving $>8.5$ or $\leq 8.5(P=0.40)$, and average dry period length $(P=0.8$; across treatments, Table 2 ). Cows enrolled from 1800 to $0600 \mathrm{~h}$ were similar to cows enrolled from 0600 to $1800 \mathrm{~h}$ based on dry period length $(P=0.95)$ and the proportion of cows with parity 1,2 , or $\geq 3(P=0.54)$, BCS $\leq 3,3.25,3.5$, or $\geq 3.75$ $(P=0.54)$, and Ca status at calving $>8.5$ or $\leq 8.5(P$ $=0.62$; Table 2 ).

\section{Serum Ca}

There was a significant effect of treatment, parity, time, treatment by time, and parity by time interactions (Table 3). Control cows had lower serum Ca levels than cows on s.c. Ca at 1 DIM (control: $7.59 \mathrm{mg} / \mathrm{dL}$; $1 \mathrm{SC}_{250}: 9.04 \mathrm{mg} / \mathrm{dL} ; 1 \mathrm{SC}_{500}: 9.60 \mathrm{mg} / \mathrm{dL} ; 2 \mathrm{SC}_{250}: 8.96$ $\mathrm{mg} / \mathrm{dL})$. However, at $2 \mathrm{DIM}, 1 \mathrm{SC}_{500}(8.85 \mathrm{mg} / \mathrm{dL})$ and $2 \mathrm{SC}_{250}(9.03 \mathrm{mg} / \mathrm{dL})$ had higher serum Ca levels than control $(8.01 \mathrm{mg} / \mathrm{dL})$ or $1 \mathrm{SC}_{250}(8.24 \mathrm{mg} / \mathrm{dL})$ cows, but no treatment differences were found at 4 and 7 DIM after treatment (Figure 1).

Serum Ca concentration before treatment application was $\leq 8.5 \mathrm{mg} / \mathrm{dL}$ in $58.6 \%$ of the cows. Although the ef- 
PROPHYLACTIC ADMINISTRATION OF SUBCUTANEOUS CALCIUM

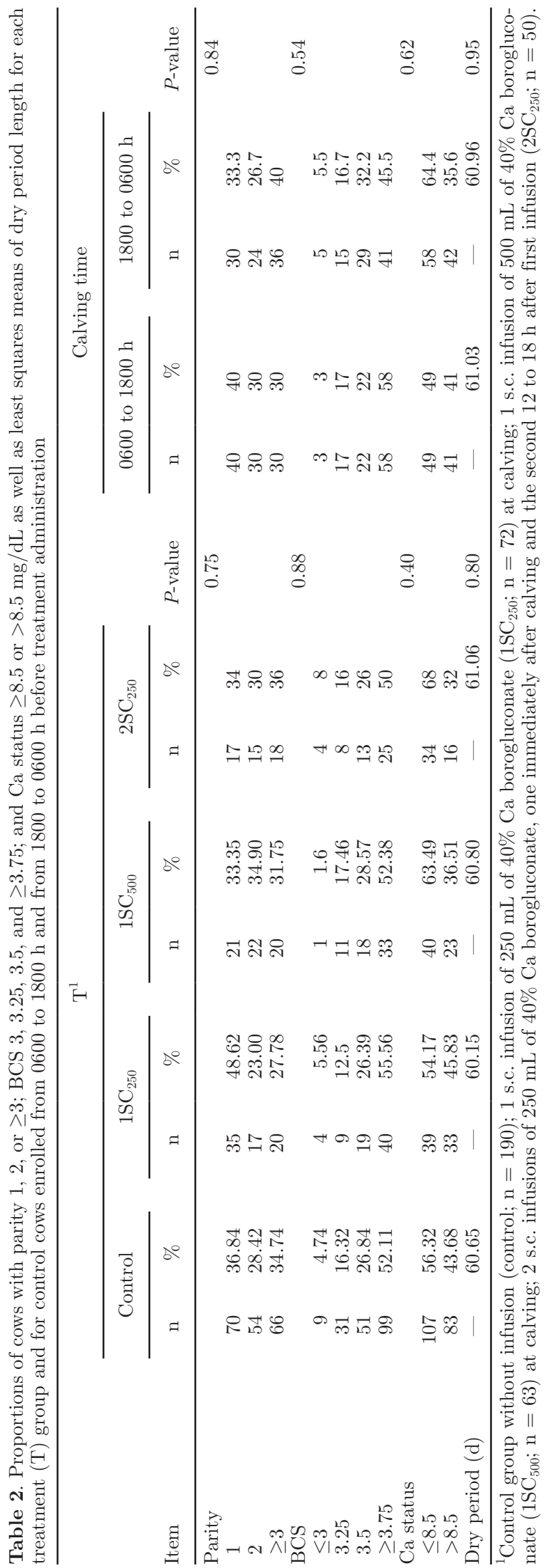

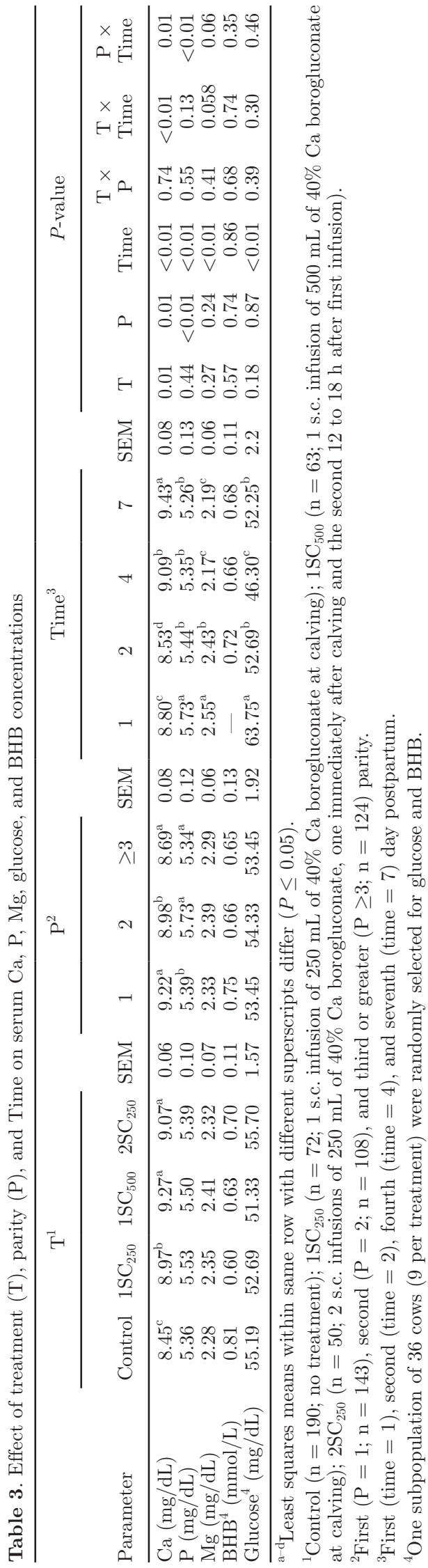


fectiveness of the anionic salt program, based on urine $\mathrm{pH}$, was evaluated once a month as part of the dairy management, this frequency might have been insufficient to ensure a good DCAD program. The proportion of cows with $\leq 8.5 \mathrm{mg} / \mathrm{dL}$ was $94.2,16.6,3.2$, and $24.0 \%$ at 1 DIM and $87.8,63.8,31.7$, and $16 \%$ at 2 DIM for control, $1 \mathrm{SC}_{250}, 1 \mathrm{SC}_{500}$, and $2 \mathrm{SC}_{250}$, respectively. The proportion of cows with SCH at 1 or 2 DIM was affected by treatment $(P<0.05$; Table 4$)$, but not by parity $(P>0.05)$. Control cows had $2.2,5.2$, and 4.5 times greater risk to develop hypocalcemia up to 2 DIM compared with $1 \mathrm{SC}_{250}, 1 \mathrm{SC}_{500}$, and $2 \mathrm{SC}_{250}$ cows, respectively (Table 3 ). Cows in parity $\geq 3$ tended to have a higher risk of $\mathrm{SCH}$ than primiparous cows $(P=0.09)$, with $52.2 \%$ for parity 1 and $64.9 \%$ for parity $\geq 3$.

To the best of our knowledge, only 2 studies have explored s.c. Ca as a prophylactic strategy for hypocalcemia. Similarly, these studies reported a treatment effect on serum Ca levels at $12 \mathrm{~h}$ ( $6 \mathrm{~g}$ of Ca; Mohebbi-Fani and Azadnia, 2012) and $24 \mathrm{~h}$ but not at $48 \mathrm{~h}$ (9.46 g of s.c. Ca administered in 2 doses $24 \mathrm{~h}$ apart; Miltenburg et al., 2016). In our study a single large dose of s.c. Ca $\left(1 \mathrm{SC}_{500}\right)$ seemed to be an effective strategy to maintain Ca homeostasis, but not $1 \mathrm{SC}_{250}$. Although in our study blood sampling was not frequent enough to capture the peak of serum Ca after treatment, at 1 DIM serum Ca levels were numerically higher for $1 \mathrm{SC}_{500}$ with $20.6 \%$ of the cows reaching serum Ca levels above $10 \mathrm{mg} /$ $\mathrm{dL}$. The high serum Ca levels in $1 \mathrm{SC}_{500}$ did not seem to negatively affect $\mathrm{Ca}$ homeostasis as previously reported after i.v. infusion of the exact same amount of $\mathrm{Ca}$ (Blanc et al., 2014). The ability of $1 \mathrm{SC}_{500}$ to sustain

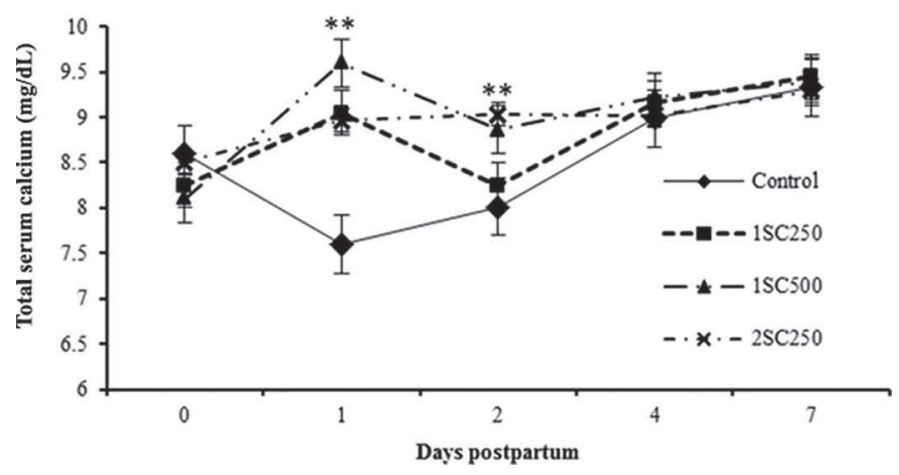

Figure 1. Total serum Ca (mean and SEM) in fresh cows: no infusion (control; $\mathrm{n}=190$ ); 1 subcutaneous (s.c.) infusion of $250 \mathrm{~mL}$ of $40 \%$ Ca borogluconate $\left(1 \mathrm{SC}_{250} ; \mathrm{n}=72\right)$ at calving; 1 s.c. infusion of $500 \mathrm{~mL}$ of $40 \% \mathrm{Ca}$ borogluconate $\left(\mathrm{SC}_{500} ; \mathrm{n}=63\right)$ at calving; 2 s.c. infusions of $250 \mathrm{~mL}$ of $40 \%$ Ca borogluconate, one immediately after calving and the second 12 to $18 \mathrm{~h}$ after first infusion $\left(2 \mathrm{SC}_{250} ; \mathrm{n}=50\right)$. Significant treatment by time differences at each time are indicated by ** $(P<0.001)$. normocalcemic levels with a single injection through a longer period of time, but no $1 \mathrm{SC}_{250}$ could likely be associated with not only the amount of Ca infused but also by the volume and irritant nature of the Ca solution. It has been shown that inflammation of subcutaneous tissues after infusion delays absorption (Miller, 1938). Although injection site lesions were minimized by using Ca solutions without glucose and limiting the dose to $50 \mathrm{~mL}$ per site, most likely there was some degree of s.c. tissue inflammation after infusion (Daitoku et al., 2007). The irritation and inflammation associated with s.c. Ca infusions could partially explain the minimal attention it has received as a prophylactic strategy for hypocalcemia; however, in the present study no obvious problems were observed with s.c. Ca administration. Based on serum Ca levels, $1 \mathrm{SC}_{500}$ and $2 \mathrm{SC}_{250}$ seem to be efficient treatment strategies to maintain normocalcemic levels. However, $1 \mathrm{SC}_{500}$ would likely be more feasible under most management systems as it requires less labor and time for implementation.

\section{Serum $P$}

Serum P levels were similar among treatments (Table 3; Figure 2). The main effect of time, parity, and parity by time interaction were significant $(P<0.01)$. Serum $P$ levels were $5.23,5.34$, and $5.71 \mathrm{mg} / \mathrm{dL}$ for first, second, and third or greater parity, respectively $(P<0.01)$. Similarly, the significant effect on serum P levels and parity was previously reported (Goff and Horst, 1998; Melendez et al., 2002). Whereas previous studies reported an increase in serum $P$ levels after calving (Goff and Horst, 1998; Melendez et al., 2002), we observed a decrease from $1(5.72 \mathrm{mg} / \mathrm{dL}), 2(5.46 \mathrm{mg} / \mathrm{dL}), 4(5.32$ $\mathrm{mg} / \mathrm{dL})$, and $7(5.21 \mathrm{mg} / \mathrm{dL})$ DIM. Before treatment administration, only $8 \%$ of the cows in our study had $\mathrm{P}$ concentrations below $4 \mathrm{mg} / \mathrm{dL}$. However, relative to our findings, Goff and Horst (1998) and Melendez et al. (2002) reported low mean serum P levels before treatment administration, $3.50 \pm 0.58$ and $3.66 \pm 0.10 \mathrm{mg} /$ $\mathrm{dL}$, respectively. This may explain the different trend in serum $\mathrm{P}$ levels over time compared with our study. Despite the statistical difference observed on $\mathrm{P}$ levels in regard to time and parity, the magnitude of the difference found in our study might be too small to imply any biological significance.

Although $\mathrm{Ca}$ and $\mathrm{P}$ homeostasis are closely related, no treatment effects on serum P levels were detected. Accordingly, previous studies reported no effects on $\mathrm{P}$ serum levels when Ca was supplemented postpartum either through oral, i.v., or s.c. infusions to prevent $\mathrm{SCH}$ (Dhiman and Sasidharan, 1999; Melendez et al., 2002; Mohebbi-Fani and Azadnia, 2012). 
Table 4. Incidence and risk ratio $(\mathrm{RR})$ of hypocalcemia, retained fetal membranes, metritis, clinical and subclinical endometritis, and culling ${ }^{1}$

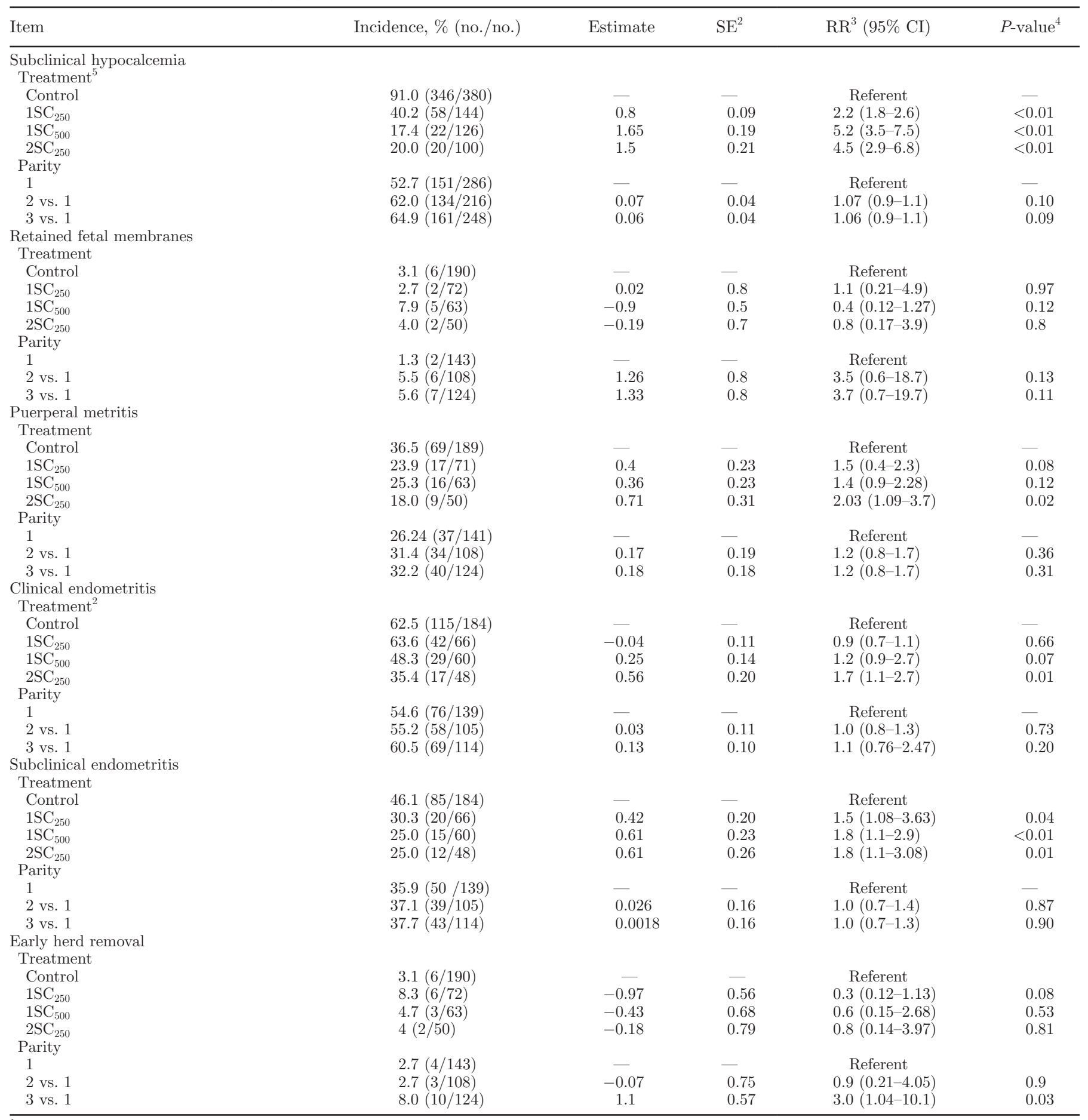

${ }^{1}$ Subclinical hypocalcemia: serum Ca concentration $\leq 8.5 \mathrm{mg} / \mathrm{dL}$ at 1 or 2 DIM. Retained fetal membranes: failure to expel fetal membranes within $24 \mathrm{~h}$ of parturition. Puerperal metritis: a discolored, foul-smelling uterine discharge with rectal temperature $>39.4^{\circ} \mathrm{C}$. Clinical endometritis: mucopurulent or purulent ( $>50 \%$ pus) uterine discharge detectable in the vagina after 21 DIM. Subclinical endometritis: a smear with $5 \%$ or more of polymorphonuclear cells. Culling were recorded up to 21 DIM.

${ }^{2}$ Standard error for estimate.

${ }^{3}$ Risk ratio, $95 \%$ confidence interval.

${ }^{4} P$-value reported for estimate.

${ }^{5}$ Treatments were no infusion (control; $\left.\mathrm{n}=190\right) ; 1$ s.c. infusion of $250 \mathrm{~mL}$ of $40 \%$ Ca borogluconate $(1 \mathrm{SC} 250 ; \mathrm{n}=72)$ at calving; 1 s.c. infusion of $500 \mathrm{~mL}$ of $40 \%$ Ca borogluconate $\left(1 \mathrm{SC}_{500} ; \mathrm{n}=63\right)$ at calving; 2 s.c. infusions of $250 \mathrm{~mL}$ of $40 \%$ Ca borogluconate, one immediately after calving and the second 12 to $18 \mathrm{~h}$ after first infusion $\left(2 \mathrm{SC}_{250} ; \mathrm{n}=50\right)$. 


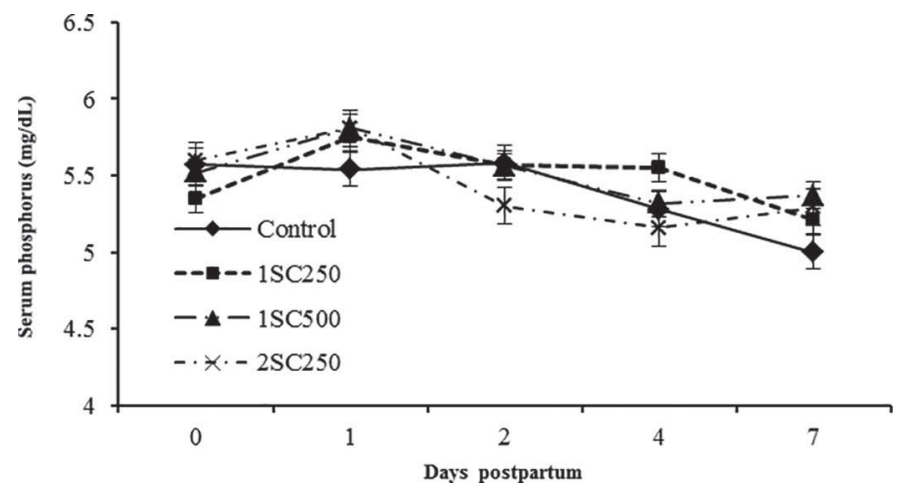

Figure 2. Serum phosphorus (mean and SEM) in fresh cows: no infusion (control; $\mathrm{n}=190$ ); 1 subcutaneous (s.c.) infusion of $250 \mathrm{~mL}$ of $40 \% \mathrm{Ca}$ borogluconate $\left(1 \mathrm{SC}_{250} ; \mathrm{n}=72\right)$ at calving; 1 s.c. infusion of $500 \mathrm{~mL}$ of $40 \% \mathrm{Ca}$ borogluconate $\left(1 \mathrm{SC}_{500} ; \mathrm{n}=63\right)$ at calving; 2 s.c. infusions of $250 \mathrm{~mL}$ of $40 \%$ Ca borogluconate, one immediately after calving and the second 12 to $18 \mathrm{~h}$ after first infusion $\left(2 \mathrm{SC}_{250} ; \mathrm{n}=50\right)$.

\section{Serum Mg}

No effects were found of treatment, parity, or their interactions on serum Mg levels (Table 3). There was an effect of time $(P<0.01)$ and a tendency for treatment by time $(P=0.058)$ and parity by time $(P=0.06)$ interactions. Serum $\mathrm{Mg}$ levels declined from calving to 4 DIM, from 2.5 to $2.1 \mathrm{mg} / \mathrm{dL}$, to increase at $7 \mathrm{DIM}$ $(2.3 \mathrm{mg} / \mathrm{dL}$; Figure 3). Similarly, Melendez et al. (2002) reported declining levels of serum $\mathrm{Mg}$ until 6 DIM that increased at 9 and 12 DIM.

\section{Serum BHB}

There were no effects of treatment, parity and time or their interactions on serum BHB levels (Table 3; Figure 4). Our study showed only $9.1 \%$ of the enrolled

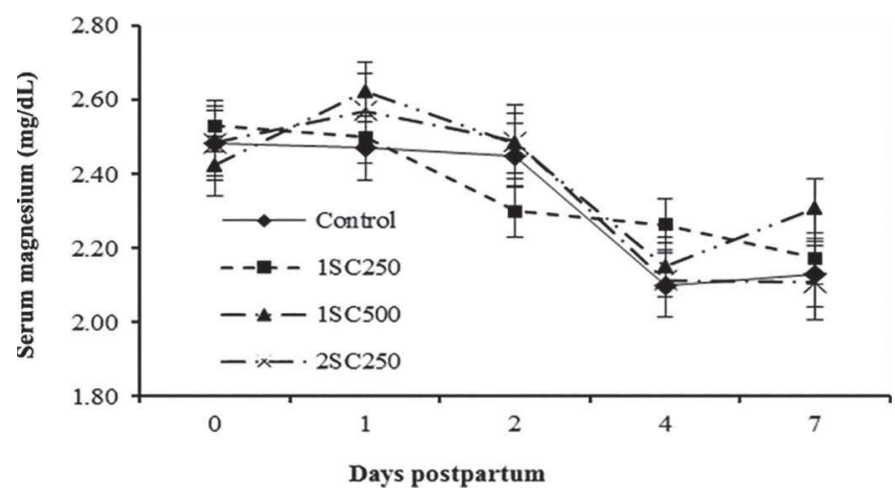

Figure 3. Serum Mg (mean and SEM) in fresh cows: no infusion (control; $\mathrm{n}=190$ ); 1 subcutaneous (s.c.) infusion of $250 \mathrm{~mL}$ of $40 \% \mathrm{Ca}$ borogluconate $\left(1 \mathrm{SC}_{250} ; \mathrm{n}=72\right)$ at calving; 1 s.c. infusion of $500 \mathrm{~mL}$ of $40 \%$ Ca borogluconate $\left(1 \mathrm{SC}_{500} ; \mathrm{n}=63\right)$ at calving; 2 s.c. infusions of $250 \mathrm{~mL}$ of $40 \% \mathrm{Ca}$ borogluconate, one immediately after calving and the second 12 to $18 \mathrm{~h}$ after first infusion $\left(2 \mathrm{SC}_{250} ; \mathrm{n}=50\right)$.

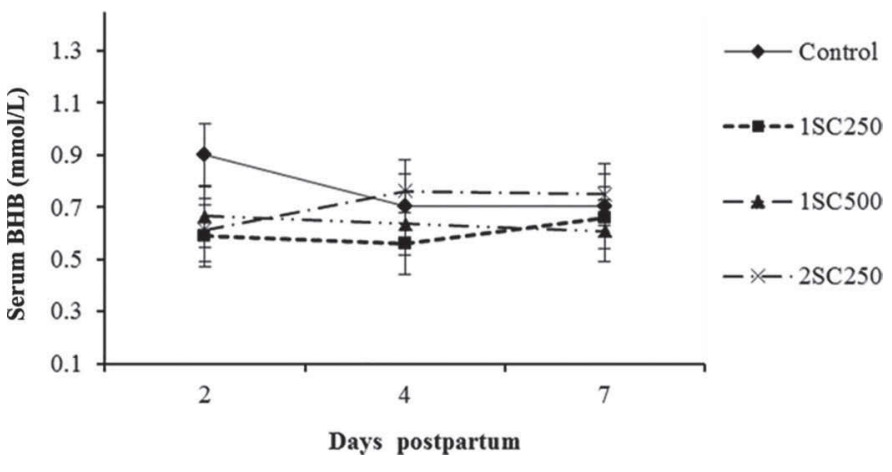

Figure 4. Serum BHB (mean and SEM) in fresh cows: no infusion (control; $\mathrm{n}=9$ ); 1 subcutaneous (s.c.) infusion of $250 \mathrm{~mL}$ of $40 \% \mathrm{Ca}$ borogluconate $\left(1 \mathrm{SC}_{250} ; \mathrm{n}=9\right.$ ) at calving; 1 s.c. infusion of $500 \mathrm{~mL}$ of $40 \% \mathrm{Ca}$ borogluconate $\left(1 \mathrm{SC}_{500} ; \mathrm{n}=9\right)$ at calving; 2 s.c. infusions of $250 \mathrm{~mL}$ of $40 \% \mathrm{Ca}$ borogluconate, one immediately after calving and the second 12 to $18 \mathrm{~h}$ after first infusion $\left(2 \mathrm{SC}_{250} ; \mathrm{n}=9\right)$.

cows had BHB $\geq 1.2 \mathrm{mmol} / \mathrm{L}$ at any of the sampled times. The lack of effect of s.c. Ca infusion on serum BHB levels is in accordance with previous studies supplementing oral Ca (Melendez et al., 2002; Oetzel and Miller, 2012) or i.v. Ca (Melendez et al., 2002). However, Goff et al. (1996) reported a decrease in BHB when using oral $\mathrm{Ca}$ supplementation as $\mathrm{Ca}$ propionate.

\section{Serum Glucose}

Serum glucose was not affected by treatment, parity, or their interactions. In agreement with our findings, Melendez et al. (2002) observed similar glucose concentrations independent of the postpartum Ca supplementation strategy. We observed a significant effect of time on glucose levels $(P<0.05$; Table 3 and Figure $5)$. In our study serum, glucose peaked at calving (112 $\mathrm{mg} / \mathrm{dL})$ and reached its nadir at 4 DIM $(46.3 \mathrm{mg} / \mathrm{dL})$. Although glucose is tightly regulated, serum glucose levels increased around calving. This is likely associated with calving hormonal changes that promote gluconeogenesis and glycogenolysis to meet the mammary gland demands for milk yield (Vazquez-Añon et al., 1994; Garverick et al., 2013).

\section{DMI 24 h After Calving}

Dry matter intake within $24 \mathrm{~h}$ after calving was greater $(P=0.01)$ for cows receiving s.c. Ca infusions than the control cows, with $12.4,13.5,15.0$, and 15.6 $\mathrm{kg} / \mathrm{d}$ of DMI for control, $1 \mathrm{SC}_{250}, 1 \mathrm{SC}_{500}$, and $2 \mathrm{SC}_{250}$, respectively (Table 5$)$. Cows on $1 \mathrm{SC}_{500}(P=0.01)$, and $2 \mathrm{SC}_{250}(P=0.004)$ had higher DMI than cows on control. This finding can be explained by the effect that $\mathrm{Ca}$ levels have on ruminal and abomasal motility (Daniel, 1983; Hansen et al., 2003; Goff, 2008). Similarly, Mar- 


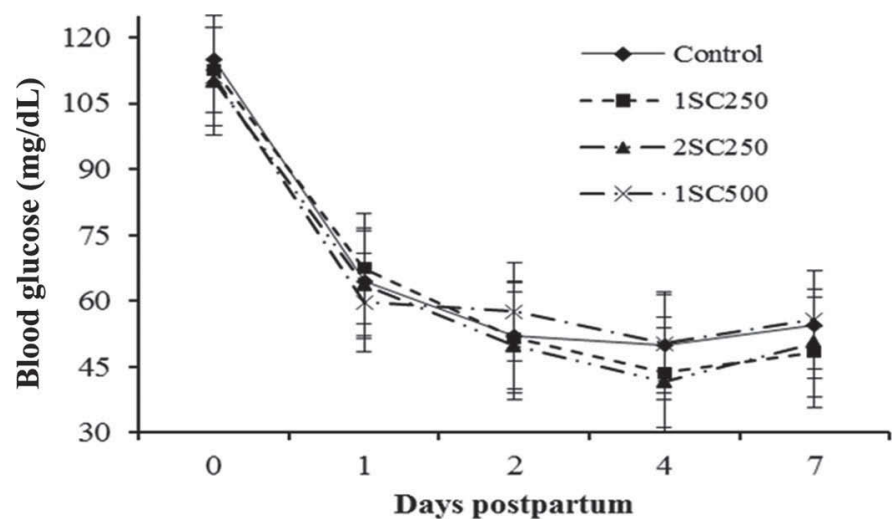

Figure 5. Blood glucose (mean and SEM) in fresh cows: no infusion (control; $\mathrm{n}=9$ ); 1 subcutaneous (s.c.) infusion of $250 \mathrm{~mL}$ of $40 \%$ Ca borogluconate $\left(1 \mathrm{SC}_{250} ; \mathrm{n}=9\right)$ at calving; 1 s.c. infusion of $500 \mathrm{~mL}$ of $40 \% \mathrm{Ca}$ borogluconate $\left(1 \mathrm{SC}_{500} ; \mathrm{n}=9\right)$ at calving; 2 s.c.infusions of $250 \mathrm{~mL}$ of $40 \% \mathrm{Ca}$ borogluconate, one immediately after calving and the second 12 to $18 \mathrm{~h}$ after first infusion $\left(2 \mathrm{SC}_{250} ; \mathrm{n}=9\right)$.

tínez et al. (2014) found lower DMI on nonpregnant and nonlactating cows induced with $\mathrm{SCH}$. Our results indicate that s.c. Ca infusions immediately after calving might be an appropriate and practical strategy to improve the cow appetite at least in early hours after postcalving. It should be noted that changes in DMI associated with s.c. postpartum supplementation were not associated with serum glucose or BHB levels.

\section{Milk Yield and Composition}

Milk yield $(P=0.4)$ and FCM $(P=0.2)$ were not affected by treatment (Table 5). Likewise, yield of milk fat and milk protein were not affected by treatments (Table 5). The parity by time interaction was significant $(P<0.05)$ for milk yield, FCM, milk fat $(\%)$, milk fat $(\mathrm{kg} / \mathrm{d})$, and milk protein $(\mathrm{kg} / \mathrm{d})$. Based on Miltenburg et al. (2016), s.c. Ca infusion had no effect on milk yield or milk composition for the first 3 DHI tests. In our study, a numerical increase occurred in FCM yield at $90 \mathrm{DIM}$ for $1 \mathrm{SC}_{250}, 1 \mathrm{SC}_{500}$, and $2 \mathrm{SC}_{250}$ cows relative to control cows $(0.7,1.3$, and $2.5 \mathrm{~kg} / \mathrm{d}$, respectively). It is likely that a large sample size might be required to declare differences in milk yield as significant.

\section{Milk SCC}

There was an effect of treatment, parity and time on SCC $(P=0.01)$. Also, the 2 -way treatment by time and parity by time interactions were significant (Table 5; Figure 6). Lower SCC was observed for $1 \mathrm{SC}_{500}(90.49$ cells $/ \mathrm{mL})$ and $2 \mathrm{SC}_{250}(82.21$ cells $/ \mathrm{mL})$ cows than for control (132.84 cells/mL) and $1 \mathrm{SC}_{250}(140.21$ cells $/ \mathrm{mL})$ cows. These results could indicate that cows in control

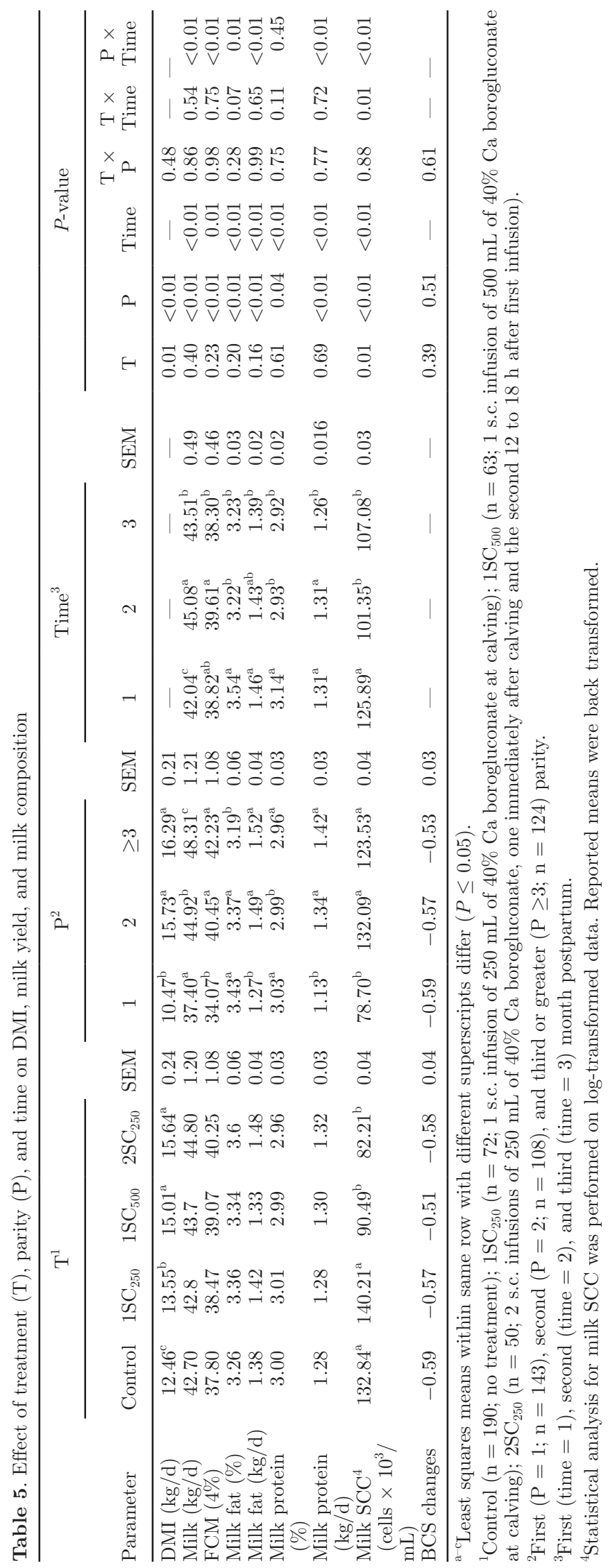

Journal of Dairy Science Vol. 99 No. 11, 2016 
and $1_{S^{250}}$ have a greater challenge to overcome IMI. These results are in accordance with early postpartum Ca levels after prophylactic administration of s.c. Ca.

Curtis et al. (1983) showed that cows with clinical milk fever were 8 times more likely to develop mastitis; however, Chamberlin et al. (2013) found that SCH at calving had no effect on SCC. It has been shown that low serum Ca levels decrease the contraction of smooth and skeletal muscle; this could directly result in poor contraction of the teat end sphincter (Goff, 2008). Although it has been hypothesized that SCH could also affect lying time, Jawor et al. (2012) failed to find postpartum differences in standing time between cows with $\mathrm{SCH}$ and cows with normocalcemia at calving. However, in the aforementioned study, cows were supplemented after calving with s.c. Ca as part of the herd health protocol, which might have confounded results.

\section{BCS Change}

From calving to $38 \pm 3$ DIM, BCS change was not affected by treatment $(P=0.39$; Table 5$)$. The lack of changes in BCS with s.c. Ca infusions is in agreement with the results of BHB and glucose. Similarly, prior studies failed to show an association between BCS change and prophylactic Ca supplementation (Melendez et al., 2003; Oetzel and Miller, 2012). Roche and Berry (2006) reported higher odds of milk fever for cows calving with $<2.5$ and $>3.5$ BCS, but Oetzel and Miller (2012) along with Martínez et al. (2012) found no differences between BCS at calving and Ca levels.

\section{Postpartum Health Outcomes and Early Herd Removal}

All models evaluating postpartum health outcomes and early herd removal were covariately adjusted by Ca status at calving (normocalcemia vs. hypocalcemia) except for SCH. However, Ca status immediately after calving was not significant and it was removed from all models.

Retained Fetal Membranes. The presence of RFM was not affected by treatment or parity (Table 4). In our study, only a small proportion of cows $(5.4 \%$; 15/375) were observed with RFM. However, previous studies indicated that RFM can range from 1.3 to $39.2 \%$ (Kelton et al., 1998). Previous research studies evaluating prophylactic strategies to prevent $\mathrm{SCH}$ found no treatment effect on RFM incidence when Ca was given orally or s.c. (Oetzel, 1996; Melendez et al., 2003; Miltenburg et al., 2016). However, prophylactic Ca infusion failed to raise serum Ca levels significantly except for Miltenburg et al. (2016) who reported higher

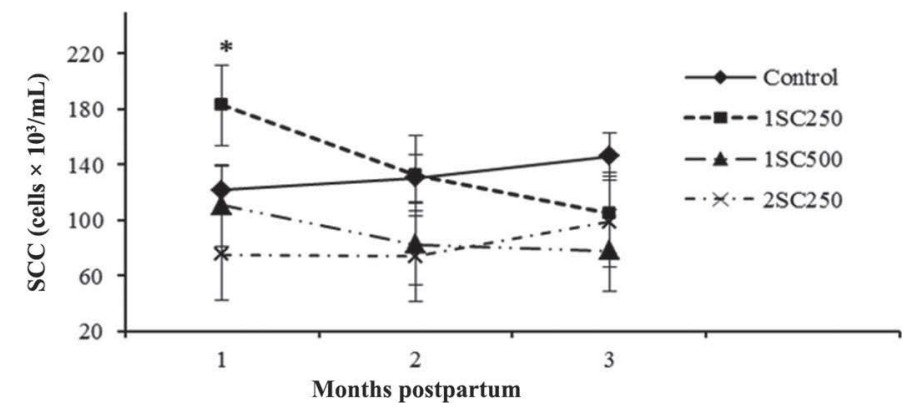

Figure 6. Milk SCC (mean and SEM) in fresh cows: no infusion (control; $\mathrm{n}=190$ ); 1 subcutaneous (s.c.) infusion of $250 \mathrm{~mL}$ of $40 \% \mathrm{Ca}$ borogluconate $\left(1 \mathrm{SC}_{250} ; \mathrm{n}=72\right)$ at calving; 1 s.c. infusion of $500 \mathrm{~mL}$ of $40 \% \mathrm{Ca}$ borogluconate $\left(1 \mathrm{SC}_{500} ; \mathrm{n}=63\right)$ at calving; 2 s.c. infusions of $250 \mathrm{~mL}$ of $40 \% \mathrm{Ca}$ borogluconate, one immediately after calving and the second 12 to $18 \mathrm{~h}$ after first infusion $\left(2 \mathrm{SC}_{250} ; \mathrm{n}=50\right)$. Significant treatment by time differences at each time are indicated by $*(P<$ $0.05)$.

Ca levels at $24 \mathrm{~h}$ but not at $48 \mathrm{~h}$. All previously cited studies fed DCAD close-up diets but not Miltenburg et al. (2016).

Curtis et al. (1983) reported that cows with clinical hypocalcemia were 3 times more likely to develop RFM. However, variety of risk factors other than Ca levels are associated with RFM incidence such as increased NEFA (LeBlanc et al., 2004; Ospina et al., 2010; Chapinal et al., 2011), low serum $\alpha$-tocopherol concentrations in the last week prepartum (LeBlanc et al., 2004), low prepartum BCS (Qu et al., 2014), and imbalanced immune responses (McNaughton and Murray, 2009). Therefore, RFM could be a syndrome that may be difficult to prevent by just supplementing $\mathrm{Ca}$ at calving day.

Puerperal Metritis. The risk to developing puerperal metritis was 2.03 times higher for control cows than cows on $2 \mathrm{SC}_{250}(P=0.02 ; 95 \% \mathrm{CI}=1.09-3.7$; Table 4). Overall, puerperal metritis incidence was $36.5,23.7,25.3$, and $18.0 \%$ for control, $1 \mathrm{SC}_{250}, 1 \mathrm{SC}_{500}$, and $2 \mathrm{SC}_{250}$, respectively, in accordance with serum $\mathrm{Ca}$ levels. Parity at calving did not affect the incidence of metritis. Previous research studies evaluating metritis incidence after prophylactic supplementation of $\mathrm{Ca}$ found no independent treatment effect if it was given orally (Melendez et al., 2003; Oetzel and Miller, 2012) or s.c. (Miltenburg et al., 2016).

In our study, overall incidence of puerperal metritis was $29.7 \%(111 / 373)$, less than reported by Melendez et al. (2003) and more than reported by Oetzel and Miller (2012) and Miltenburg et al. (2016). Our study had an experienced dairy veterinarian responsible for performing fresh cow checks and identifying metritis. Other studies (Oetzel and Miller, 2012; Miltenburg et al., 2016) relied on less qualified farm personnel for metritis diagnosis. 
Clinical and Subclinical Endometritis. Control cows had a higher risk of clinical endometritis compared with $1 \mathrm{SC}_{500}(P=0.07 ; \mathrm{RR}=1.2 ; 95 \% \mathrm{CI}=$ $0.9-1.7)$ and $2 \mathrm{SC}_{250}$ cows $(P<0.01 ; \mathrm{RR}=1.7 ; 95 \% \mathrm{CI}$ $=1.2-2.6$; Table 4$)$. Control cows were $1.5,1.8$, and 1.8 times more likely to develop subclinical endometritis compared with $1 \mathrm{SC}_{250}, 1 \mathrm{SC}_{500}$, and $2 \mathrm{SC}_{250}$ cows, respectively (Table 4). Parity and Ca status did not influence incidence of clinical or subclinical endometritis (Table 4). The present study had $56.7 \%$ incidence of clinical endometritis and $29.3 \%$ of subclinical endometritis (105/385). In contrast, Martínez et al. (2012) showed that $\mathrm{Ca}$ status at calving influenced risk of puerperal metritis. It has been shown that hypocalcemia causes immunosuppression by depleting intracellular Ca stores in blood mononuclear cells (Kimura et al., 2006) and reducing proportion of neutrophils with phagocytic activity (Martínez et al., 2012). Thus, hypocalcemic cows could be more susceptible to bacterial diseases and periparturient disorders such as mastitis (Curtis et al., 1983) and metritis (Martínez et al., 2012).

Early Herd Removal. Early herd removal (up to 21 DIM) was not influenced by treatment; however, a parity effect was present (Table 4). Older cows (parity $\geq 3$ ) were at a greater risk for culling than cows on their first parity $(P=0.03 ; \mathrm{RR}=3.0 ; 95 \% \mathrm{CI}=1.04-10.1)$. Similar to our results, studies evaluating the effect of s.c. (Miltenburg et al., 2016) or oral (Oetzel and Miller, 2012) Ca supplementation at calving found no effect in culling. Nevertheless, Ca levels at calving have been reported to be important predictors of culling risk at $\leq 30$ DIM (Oetzel and Miller, 2012). Martínez et al. (2012) found no effect of Ca status and parity on culling, whereas Duffield et al. (2005) found that cows with $\mathrm{SCH}$, but not clinical milk fever, had a greater risk of culling in early lactation than cows with normal Ca concentrations (above $7.2 \mathrm{mg} / \mathrm{dL}$ ).

\section{CONCLUSIONS}

Various regimens of s.c. Ca infusions after calving increased total serum $\mathrm{Ca}$ at $24 \mathrm{~h}\left(\mathrm{SSC}_{250}, 1 \mathrm{SC}_{500}\right.$, and $\left.2 \mathrm{SC}_{250}\right)$ and $48 \mathrm{~h}\left(1 \mathrm{SC}_{500}\right.$ and $\left.2 \mathrm{SC}_{250}\right)$ relative to the control. However, it had no effect on serum concentrations of $\mathrm{P}, \mathrm{Mg}, \mathrm{BHB}$, and glucose. Somatic cell count was lower for $1 \mathrm{SC}_{500}$ and $2 \mathrm{SC}_{250}$ relative to control. Milk yield, RFM, and culling were not affected by s.c. Ca administration, but a decline occurred in the incidence of puerperal metritis as well as clinical and subclinical endometritis. These results show that $2 \mathrm{SC}_{250}$ seems the most effective treatment to maintain serum $\mathrm{Ca}$ within physiological limits; however, $1 \mathrm{SC}_{500}$ could be an effective treatment strategy when labor and facilities are limiting factors. Due to the potential to improve mammary and uterus health after calving, the effects of postpartum s.c. Ca infusion on the immune system warrant further evaluation.

\section{ACKNOWLEDGMENTS}

The authors express gratitude to the managers and employees of Pars Holding Company and Khoramdareh Plain Agricultural Complex (Zanjan, Iran) for allowing us access to their cows, facilities, and herd records. A special thanks is given to Ehsan Mahjuobi from the Department of Animal Sciences at the University of Zanjan (Iran) for reviewing this manuscript. Funding for this study was provided by Pars Holding Company (Tehran, Iran) and by the University of Zanjan (Iran).

\section{REFERENCES}

AOAC. 1990. Official Methods of Analysis. Volume 2. 15th ed. Association of Official Analytical Chemists, Arlington, VA.

Baginski, E. S., S. S. Marie, W. L. Clark, and B. Zak. 1973. Direct microdetermination of serum calcium. Clin. Chim. Acta 46:49-54.

Blanc, C. D., M. Van der List, S. S. Aly, H. A. Rossow, and N. Silvadel-Río. 2014. Blood calcium dynamics after prophylactic treatment of subclinical hypocalcemia with oral or intravenous calcium. J. Dairy Sci. 97:6901-6906.

Borsberry, S., and H. Dobson. 1989. Periparturient diseases and their effect on reproductive performance in five dairy herds. Vet. Rec. 124:217-219.

Brozos, C., V. S. Mavrogianni, and G. C. Fthenakis. 2011. Treatment and control of peri-parturient metabolic diseases: Pregnancy toxemia, hypocalcemia, hypomagnesemia. Vet. Clin. North Am. Food Anim. Pract. 27:105-113.

Chamberlin, W. G., J. R. Middleton, J. N. Spain, G. C. Johnson, M. R. Ellersieck, and P. Pithua. 2013. Subclinical hypocalcemia, plasma biochemical parameters, lipid metabolism, postpartum disease, and fertility in postparturient dairy cows. J. Dairy Sci. 96:7001-7013.

Chapinal, N., M. Carson, T. F. Duffield, M. Capel, S. Godden, M. Overton, J. E. P. Santos, and S. J. LeBlanc. 2011. The association of serum metabolites with clinical disease during the transition period. J. Dairy Sci. 94:4897-4903.

Curtis, C., H. Erb, C. Sniffen, R. Smith, P. Powers, M. Smith, M. White, R. Hillman, and E. Pearson. 1983. Association of parturient hypocalcemia with eight periparturient disorders in Holstein cows. J. Am. Vet. Med. Assoc. 183:559-561.

Daitoku, D., T. Kurose, E. Mori, M. Hashimoto, and S. Kawamata. 2007. Changes in the rat subcutaneous connective tissue after saline and histamine injection in relation to fluid storage and excretion. Arch. Histol. Cytol. 70:29-41.

Daniel, R. 1983. Motility of the rumen and abomasum during hypocalcaemia. Can. J. Comp. Med. 47:276-280.

Dhiman, T., and V. Sasidharan. 1999. Effectiveness of calcium chloride in increasing blood calcium concentrations of periparturient dairy cows. J. Anim. Sci. 77:1597-1605.

Dohoo, I. R., W. Martin, and H. Stryhn. 2003. Veterinary Epidemiologic Research. AVC Inc., Charlottetown, Prince Edward Island, Canada.

Duffield, T., S. LeBlanc, and K. Leslie. 2005. Impact of subclinical metabolic disease on risk of early lactation culling. J. Dairy Sci. 88:199-200. (Abstr.).

Endres, D. B., and R. K. Rude. 1999. Mineral and bone metabolism. Pages 1395-1457 in Tietz Textbook of Clinical Chemistry. 3rd ed. C. A. Burtis, and E. R. Ashwood, ed. W.B. Saunders, Philadelphia, PA. 
Garverick, H., M. Harris, R. Vogel-Bluel, J. Sampson, J. Bader, W. Lamberson, J. Spain, M. Lucy, and R. Youngquist. 2013. Concentrations of nonesterified fatty acids and glucose in blood of periparturient dairy cows are indicative of pregnancy success at first insemination. J. Dairy Sci. 96:181-188.

Gilbert, R. O., S. T. Shin, C. L. Guard, H. N. Erb, and M. Frajblat. 2005. Prevalence of endometritis and its effects on reproductive performance of dairy cows. Theriogenology 64:1879-1888.

Goff, J. P. 1999. Treatment of calcium, phosphorus, and magnesium balance disorders. Vet. Clin. North Am. Food Anim. Pract. 15:619-639.

Goff, J. P., and R. Horst. 1997. Effects of the addition of potassium or sodium, but not calcium, to prepartum rations on milk fever in dairy cows. J. Dairy Sci. 80:176-186.

Goff, J. P., and R. Horst. 1998. Use of hydrochloric acid as a source of anions for prevention of milk fever. J. Dairy Sci. 81:2874-2880.

Goff, J. P., R. Horst, P. Jardon, C. Borelli, and J. Wedam. 1996. Field trials of an oral calcium propionate paste as an aid to prevent milk fever in periparturient dairy cows. J. Dairy Sci. 79:378-383.

Goff, J. P. 2008. Transition cow immune function and interaction with metabolic diseases. Pages 45-57 in Proc. Tri-State Dairy Nutrition Conference. M. Eastridge, ed. The Ohio State University.

Hansen, S., P. Nørgaard, C. Pedersen, R. J. Jørgensen, L. Mellau, and J. Enemark. 2003. The effect of subclinical hypocalcaemia induced by $\mathrm{Na}_{2}$ EDTA on the feed intake and chewing activity of dairy cows. Vet. Res. Commun. 27:193-205.

Jawor, P. E., J. M. Huzzey, S. J. LeBlanc, and M. A. G. von Keyserlingk. 2012. Associations of subclinical hypocalcemia at calving with milk yield, and feeding, drinking, and standing behaviors around parturition in Holstein cows. J. Dairy Sci. 95:1240-1248.

Kelton, D. F., K. D. Lissemore, and R. E. Martin. 1998. Recommendations for recording and calculating the incidence of selected clinical diseases of dairy cattle. J. Dairy Sci. 81:2502-2509.

Kimura, K., T. A. Reinhardt, and J. P. Goff. 2006. Parturition and hypocalcemia blunts calcium signals in immune cells of dairy cattle. J. Dairy Sci. 89:2588-2595.

LeBlanc, S., T. Herdt, W. Seymour, T. Duffield, and K. Leslie. 2004. Peripartum serum vitamin E, retinol, and beta-carotene in dairy cattle and their associations with disease. J. Dairy Sci. 87:609-619.

Liang, K. Y., and S. L. Zeger. 1986. Longitudinal data analysis using generalized linear models. Biometrika 73:13-22.

Littell, R., P. Henry, and C. Ammerman. 1998. Statistical analysis of repeated measures data using SAS procedures. J. Anim. Sci. $76: 1216-1231$

Martínez, N., C. A. Risco, F. S. Lima, R. S. Bisinotto, L. F. Greco, E. S. Ribeiro, F. Maunsell, K. Galvão, and J. E. P. Santos. 2012. Evaluation of peripartal calcium status, energetic profile, and neutrophil function in dairy cows at low or high risk of developing uterine disease. J. Dairy Sci. 95:7158-7172.

Martinez, N., L. D. P. Sinedino, R. S. Bisinotto, E. S. Ribeiro, G. C. Gomes, F. S. Lima, L. F. Greco, C. A. Risco, K. N. Galvão, D. Taylor-Rodriguez, J. P. Driver, W. W. Thatcher, and J. E. P. Santos. 2014. Effect of induced subclinical hypocalcemia on physiological responses and neutrophil function in dairy cows. J. Dairy Sci. 97:874-887.

McLaren, C. J., K. D. Lissemore, T. F. Duffield, K. E. Leslie, D. F Kelton, and B. Grexton. 2006. The relationship between herd level disease incidence and a return over feed index in Ontario dairy herds. Can. Vet. J. 47:767-773.

McNaughton, A., and R. Murray. 2009. Structure and function of the bovine fetomaternal unit in relation to the causes of retained fetal membranes. Vet. Rec. 165:615-622.

Melendez, P., A. Donovan, C. A. Risco, M. B. Hall, R. Littell, and J. Goff. 2002. Metabolic responses of transition Holstein cows fed anionic salts and supplemented at calving with calcium and energy. J. Dairy Sci. 85:1085-1092.

Melendez, P., G. A. Donovan, C. A. Risco, R. Littell, and J. P. Goff. 2003. Effect of calcium-energy supplements on calving-related dis- orders, fertility and milk yield during the transition period in cows fed anionic diets. Theriogenology 60:843-854.

Miller, R. G. 1938. The influence of inflammation on the absorption of substances of varied diffusibility. J. Exp. Med. 67:619-641.

Miltenburg, C. L., T. F. Duffield, D. Bienzle, E. L. Scholtz, and S. J. LeBlanc. 2016. Randomized clinical trial of a calcium supplement for improvement of health in dairy cows in early lactation. J. Dairy Sci. 99:6550-6562.

Mohebbi-Fani, M., and P. Azadnia. 2012. The effect of subcutaneous injection of calcium borogluconate on serum levels of calcium phosphorus and magnesium in newly calved cows. Comp. Clin. Pathol. 21:1647-1652.

Moore, S., M. VandeHaar, B. Sharma, T. Pilbeam, D. Beede, H. Bucholtz, J. Liesman, R. Horst, and J. Goff. 2000. Effects of altering dietary cation-anion difference on calcium and energy metabolism in peripartum cows. J. Dairy Sci. 83:2095-2104.

NRC. 2001. Nutrient Requirements of Dairy Cattle. 7th rev. ed. Natl. Acad. Press, Washington, DC.

Oetzel, G. K. 1988. Parturient paresis and hypocalcemia in ruminant livestock. Vet. Clin. North Am. Food Anim. Pract. 4:351-364.

Oetzel, G. R. 1996. Effect of calcium chloride gel treatment in dairy cows on incidence of periparturient diseases. J. Am. Vet. Med. Assoc. 209:958-961.

Oetzel, G. R., and M. Eastridge. 2013. Minimizing hypocalcemia during early lactation. Pages 23-34 in Proc. 22nd Tri-State Dairy Nutrition Conference, Fort Wayne, IN, April 23-24, 2013. Michigan State University.

Oetzel, G. R., and B. E. Miller. 2012. Effect of oral calcium bolus supplementation on early-lactation health and milk yield in commercial dairy herds. J. Dairy Sci. 95:7051-7065.

Oetzel, G. R., J. D. Olson, C. R. Curtis, and M. J. Fettman. 1988 Ammonium chloride and ammonium sulfate for prevention of parturient paresis in dairy cows. J. Dairy Sci. 71:3302-3309.

Ospina, P., D. Nydam, T. Stokol, and T. Overton. 2010. Evaluation of nonesterified fatty acids and $\beta$-hydroxybutyrate in transition dairy cattle in the northeastern United States: Critical thresholds for prediction of clinical diseases. J. Dairy Sci. 93:546-554.

Qu, Y., A. Fadden, M. Traber, and G. Bobe. 2014. Potential risk indicators of retained placenta and other diseases in multiparous cows. J. Dairy Sci. 97:4151-4165.

Ramos-Nieves, J. M., B. J. Thering, M. R. Waldron, P. W. Jardon, and T. R. Overton. 2009. Effects of anion supplementation to lowpotassium prepartum diets on macromineral status and performance of periparturient dairy cows. J. Dairy Sci. 92:5677-5691.

Reinhardt, T. A.. J. D. Lippolis, B. J. McCluskey, J. P. Goff, and R. L. Horst. 2011. Prevalence of subclinical hypocalcemia in dairy herds. Vet. J. 188:122-124.

Roberts, T., N. Chapinal, S. J. LeBlanc, D. F. Kelton, J. Dubuc, and T. F. Duffield. 2012. Metabolic parameters in transition cows as indicators for early-lactation culling risk. J. Dairy Sci. 95:30573063.

Roche, J. R., and D. P. Berry. 2006. Periparturient climatic, animal, and management factors influencing the incidence of milk fever in grazing systems. J. Dairy Sci. 89:2775-2783.

Sampson, J. D., J. N. Spain, C. Jones, and L. Carstensen. 2009. Effects of calcium chloride and calcium sulfate in an oral bolus given as a supplement to postpartum dairy cows. Vet. Ther. 10:131-139.

Sheldon, I. M., G. S. Lewis, S. LeBlanc, and R. O. Gilbert. 2006 Defining postpartum uterine disease in cattle. Theriogenology 65:1516-1530

Vazquez-Añon, M., S. Bertics, M. Luck, R. R. Grummer, and J. Pinheiro. 1994. Peripartum liver triglyceride and plasma metabolites in dairy cows. J. Dairy Sci. 77:1521-1528.

Wildman, E., G. Jones, P. Wagner, R. Boman, H. Troutt Jr., and T. Lesch. 1982. A dairy cow body condition scoring system and its relationship to selected production characteristics. J. Dairy Sci. 65:495-501. 